\title{
Status of Different Diseases of Cotton under South Gujarat Region of India
}

\author{
Prashant B. Sandipan*, R. K. Patel, G. O. Faldu and D. M. Patel \\ Main Cotton Research Station (MCRS), Navsari Agricultural University (NAU), \\ Surat 395007 (Gujarat), India \\ *Corresponding author
}

\section{A B S T R A C T}

\begin{tabular}{l} 
Key w or d s \\
$\begin{array}{l}\text { Cotton, Survey, } \\
\text { Intensity, Pest, } \\
\text { Disease }\end{array}$ \\
\hline Article Info \\
\hline $\begin{array}{l}\text { Accepted: } \\
\text { 15 September } 2019 \\
\text { Available Online: } \\
\text { 10 October } 2019\end{array}$ \\
\hline
\end{tabular}

In this experiment, different districts of South Gujarat were closely examined for various diseases in different cultivars/ Bt hybirds. A roving survey was conducted on cultivars' field during the crop season and a fix point survey on cotton crop was conducted periodically at Research farm, Surat. During the season, only Bacterial leaf blight disease was found on G. Cot. Hy. 12. The incidence of Bacterial leaf blight disease (BLB) was noticed from $33^{\text {rd }}$ to $50^{\text {th }}$ standard week with the maximum disease intensity in the third week of October $(22.5 \%)$ i.e. in $42^{\text {nd }}$ Met. week. Results indicated that Bacterial leaf blight (BLB) disease has positive correlation with the maximum and minimum temperature and sunshine hour for the disease development. Survey was conducted on farmer's field as well as on Research farm. Bacterial leaf blight incidence varied from 0.0 to 22.5 PDI and Alternaria leaf spot disease varied from 0.0 to 12.0 PDI in different cultivars/ hybrids on Research farm. Whereas, in case of farmer's field, roving survey was mostly carried out on BG II hybrids, the BLB incidence was in the range of 0.0 to $4.5 \%, 0.0$ to $12.0 \%$ and 2.0 to 4.5 PDI in Surat, Bharuch and Narmada districts, respectively. Moreover, Alternaria leaf spot disease was observed to the tune of 0.0 to $8.0 \%, 0.0$ to $10.0 \%$ and 0.0 to $1.0 \mathrm{PDI}$ in Surat, Bharuch and Narmada district, respectively.

\section{Introduction}

Cotton is called as "The White Gold" of "The king fibers" which aggregates a pre-eminent status and a leading role among all the cash crops in the country and is the foremost raw material for booming a textile industry. Proper awareness with the emphasis on crop improvement, crop production techniques, crop protection technologies and other value addition parts are of the overriding importance in ensuring sustainability of cotton production and also livelihood security for the cotton growing farmers.

The crop is affected by abundant pests, diseases and weeds etc causing serious economic losses in a crop. In the post $\mathrm{Bt}$ cotton era (2002 onwards) sucking pests like Aphids, Jassids, Thrips, Whitefly, Mealybugs, 
Myrid bugs and Mites continue to ravage the cotton crop and pose a serious threat to sustain and enhance cotton productivity (Tanweer, 2013) and now the pink bollworm a serious thread remains. In India, 30 diseases have been reported for cotton crop. Out of these, 17 are caused by pathogens of fungal origin, four of bacterial nature, two are of nematodes and many known and unknown viruses and physiological disorders (Sekhon et al., 2008).

Among the diseases, Bacterial blight caused by Xanthomonas malvacearum and boll rot complex is the major constraints.

This pathogen infects almost all crop stages and causes considerable loss in the seed cotton yield, seed index, oil percentage and ginning out turn (Meshram and Raj, 1988 and Shelke et al., 2012).

The bacterial blight is the most wide spread and destructive disease reported to cause yield losses of about 10 to 30 per cent (Kalpana et al., 2004, Mishra, Krishna, 2001 and Sandipan et al., 2016) and also affect the quality of lint (Sharma and Chauhan, 1985).

Under natural bacterial blight infection, boll yield losses up to $35 \%$ have been reported (Sheoraj and Verma, 1988).

Bacterial leaf blight, boll rots, wilts and leaf spots are the most destructive cotton diseases and are also known to cause considerable losses in yield (Chopra, 1977 and Bashi et al., 1983). Continuous rain and moist condition, injudicious use of nitrogen fertilizer and irrigation create most favourable condition for the fungal foliar diseases.

Losses due to Alternaria leaf spot (26.6\%), grey mildew $(29.2 \%)$ and Myrothecium leaf spot $(29.1 \%)$ have been reported. This on the whole state of affairs leads to felt a closer inspection of the diseases those were present on cotton crop under South Gujarat region, hence systemic explorations on various cotton diseases were carried out.

\section{Major Diseases of Cotton}

Bacterial blight (Xanthomonas campestris pv malvacearum (Smith) Dye), Maharashtra, Gujarat, Karnataka

Cotton leaf curl (Gemini virus), North zone (Potential threat)

Alternaria leaf spot (Alternaria macrospora Zimm.), Maharashtra, Gujarat, Karnataka

Grey mildew (Ramularia areola Atk.), Central $\&$ South zone (Emerging)

Myrothecium leaf spot (Myrothecium roridum Tode ex Fr.), Madhya Pradesh

Leaf Rust (Phakopsora gossypii (Arth) Hirat F.), Karnataka, Andhra Pradesh (Emerging)

Cercospora leaf spots (Cercospora gossypina Southw.), Andhra Pradesh (Minor)

Helminthosporium leaf spot (Helminthosporium spiciferum (Bain) Nicot.), Andhra Pradesh (Minor)

Anthracnose (Colletototricum gossypsii Southw.), South zone (Minor)

Tobacco streak virus (Ilar virus), Andhra Pradesh (Emerging)

Wilt (Fusarium oxysporum f. sp. vasinfectum (Atk.) Snyder \& Hansen), Restricted to diploids

New wilt/sudden wilt (Parawilt)

Root rot (Rhizoctonia solani Kuhn, $R$. bataticola (Taub) Butler), Scattered 
Leaf reddening almost all the pockets

Verticillium wilt (Verticillium dahliae Khleb.), Tamil Nadu, Karnataka

\section{Materials and Methods}

In South Gujarat region, survey of the major diseases of cotton crop was carried out in different fields in various districts. Bt cotton fields from different areas were selected randomly on the survey route.

In each field, plants were selected at random and the severity for different diseases was recorded. The range of severity of disease intensity was calculated for foliar diseases as the incidence of particular diseases in their respective areas. Five leaves from lower part and 5 leaves from middle/ plant were selected by using 0-4 scale as given by (Sheoraj, 1989) and then these grades were converted into per cent disease intensity (PDI) by using the formula given by Wheeler (1969).

$$
\begin{aligned}
& \text { Disease incidence (\%) } \\
& \text { No. of infected plants } \\
& \text { - } \\
& \text { No. of leaves observed x Max. Grade }
\end{aligned}
$$

\section{For, Bacterial leaf blight (BLB) disease}

\begin{tabular}{|l|l|}
\hline Score & Description \\
\hline 0 & $\begin{array}{l}\text { DF= Immune, completely free } \\
\text { from bacterial blight }\end{array}$ \\
\hline 1 & $\begin{array}{l}\text { R= Resistant, nearly 1 mm in } \\
\text { diameter, not coalescing, } \\
\text { reddish, not angular, veins } \\
\text { free }\end{array}$ \\
\hline 2 & $\begin{array}{l}\text { MR= Moderately resistant, } \\
\text { leaf area covered up to 2- 10 } \\
\%\end{array}$ \\
\hline 3 & $\begin{array}{l}\text { MS= Moderately susceptible, } \\
\text { infection 11-20\% }\end{array}$ \\
\hline 4 & $\begin{array}{l}\mathrm{S}=\text { Susceptible, infection } \\
\text { more than 20\% }\end{array}$ \\
\hline
\end{tabular}

\section{For, Alternaria leaf spot (ALS) disease}

\begin{tabular}{|l|l|}
\hline Score & Description \\
\hline 0 & No infection \\
\hline 1 & $\begin{array}{l}\text { Few < 2mm, scattered, brown } \\
\text { spots, < 5 leaf area covered }\end{array}$ \\
\hline 2 & $\begin{array}{l}\text { Spots bigger, 3 mm, not } \\
\text { coalescing, brown and 6-20 \% } \\
\text { leaf area covered }\end{array}$ \\
\hline 3 & $\begin{array}{l}\text { Spots 3-5 mm, irregular in } \\
\text { shape-coalescing, 21-40 \% } \\
\text { leaf area covered }\end{array}$ \\
\hline 4 & $\begin{array}{l}\text { Spots coalescing to form } \\
\text { bigger lesions, irregular > 40 } \\
\% \text { leaf area covered }\end{array}$ \\
\hline
\end{tabular}

\section{Results and Discussion}

A roving survey was conducted on cultivars' field during the crop season and a fix point survey on cotton was conducted periodically at Research farm. On Research farm, periodically observations were recorded on $\mathrm{G}$. Cot. Hy. 12 revealed that Bacterial leaf blight disease appeared during the second week of August $(1.0 \%)$ i.e. in $33^{\text {rd }}$ Met. week and then gradually developed and reached at its peak in the third week of October $(22.5 \%)$ i.e. in $42^{\text {nd }}$ Met. week. The susceptible cultivars viz., LRA 5166 showed Bacterial leaf blight intensity to the tune of 0.0 to 22.5 per cent PDI moreover, non $\mathrm{Bt}$ cotton was more susceptible to the Bacterial leaf blight disease and also to Alternaria leaf spot disease.

During 30 - 45 DAS (vegetative stage of the crop), the BLB and ALS was more pronounced on the lower leaves of the cotton crop. Alternaria leaf spot disease was observed to the tune of 0.0-12.0 PDI in the cultivar G. Cot.100 as shown in the Table : 1 \& Graph: 1 \& 2.

Roving survey was conducted in Surat, Bharuch and Narmada districts on farmer's field where the mostly BG II hybrids were cultivated. 
Table.1 Observations on the occurrence of the diseases (in farmer's field and research farm) during 2017-18

\begin{tabular}{|c|c|c|c|c|c|c|c|}
\hline \multirow[t]{2}{*}{$\begin{array}{l}\text { Sr. } \\
\text { No. }\end{array}$} & \multirow[t]{2}{*}{ District } & \multirow[t]{2}{*}{ Taluka } & \multirow[t]{2}{*}{$\begin{array}{l}\text { Location/ } \\
\text { Village }\end{array}$} & \multirow[t]{2}{*}{ Month } & \multirow[t]{2}{*}{$\begin{array}{c}\text { Variety/ } \\
\text { Hybrids/cultivars }\end{array}$} & \multicolumn{2}{|c|}{$\begin{array}{c}\text { Disease (PDI) } \\
\text { (Range) }\end{array}$} \\
\hline & & & & & & BLB & ALS \\
\hline \multirow[t]{15}{*}{1} & \multirow[t]{15}{*}{ Surat } & \multirow[t]{12}{*}{ Choryasi } & \multirow{12}{*}{$\begin{array}{c}\text { MCRS } \\
21.10 \text { '1" }{ }^{\circ} \mathrm{N} \\
72.47,57^{\prime}{ }^{\circ} \mathrm{E}\end{array}$} & \multirow{12}{*}{$\begin{array}{l}\text { September } \\
\text { to } \\
\text { November }\end{array}$} & GN Cot. 25 & $0.0-0.0$ & $0.0-0.0$ \\
\hline & & & & & GN Cot. Hy. 14 & $0.0-4.0$ & $0.0-1.5$ \\
\hline & & & & & G. Cot. Hy.10 BG II & $0.0-13.5$ & $0.0-3.5$ \\
\hline & & & & & LRA 5166 & $0.0-22.5$ & $1.0-2.5$ \\
\hline & & & & & G. Cot. Hy. 6 & $0.0-8.0$ & $0.0-3.0$ \\
\hline & & & & & G. Cot. Hy. 8 & $0.0-13.0$ & $0.0-9.0$ \\
\hline & & & & & G. Cot. Hy. 12 & $0.0-22.5$ & $0.0-0.0$ \\
\hline & & & & & G. Cot. Hy. 6 BG II & $0.0-4.0$ & $1.0-2.0$ \\
\hline & & & & & G. Cot. Hy. 8 BG II & $0.0-10.0$ & $1.0-7.5$ \\
\hline & & & & & G. Cot. Hy. 12 BG II & $2.0-6.5$ & $0.0-2.0$ \\
\hline & & & & & G.Cot. 20 & $0.0-12.5$ & $0.0-3.5$ \\
\hline & & & & & G. Cot. 100 & - & $0.0-12.0$ \\
\hline & & Mangrol & $\begin{array}{c}\text { Vad } \\
21.30^{\prime} 11^{\circ} \mathrm{N} \\
73.16^{\prime} 27^{\circ}{ }^{\circ} \mathrm{E}\end{array}$ & \multirow[t]{3}{*}{ October } & G. Cot. Hy. 8 BG II & $2.0-3.0$ & $5.0-6.0$ \\
\hline & & Mangrol & $\begin{array}{c}\text { Ubhariya } \\
21.30^{\prime} 57^{\prime \prime}{ }^{\circ} \mathrm{N} \\
73.199^{\prime} 56^{\circ}{ }^{\circ} \mathrm{E}\end{array}$ & & Ajeet 155 BG II & $0.0-1.0$ & $5.0-8.0$ \\
\hline & & Mangrol & $\begin{array}{c}\text { Mosali } \\
21.44^{\prime} 53^{\prime \prime}{ }^{\circ} \mathrm{N} \\
73.14^{\prime} 98^{\circ}{ }^{\circ} \mathrm{E}\end{array}$ & & ATM BG II & $1.0-4.5$ & $0.0-2.0$ \\
\hline \multirow[t]{6}{*}{2} & \multirow[t]{6}{*}{ Bharuch } & Jhagadia & $\begin{array}{c}\text { Dharoli } \\
21.36 \text { ' } 16^{\circ}{ }^{\circ} \mathrm{N} \\
73.14,58^{\prime \prime}{ }^{\circ} \mathrm{E}\end{array}$ & October & Bharma Bt BG II & $0.0-2.5$ & $8.0-10.0$ \\
\hline & & \multirow[t]{3}{*}{ Valia } & $\begin{array}{c}\text { Merapur } \\
21.29^{\prime} 43 \text { " }{ }^{\circ} \mathrm{N} \\
73.19^{\prime} 56^{\circ}{ }^{\circ} \mathrm{E}\end{array}$ & October & Bharma Bt BG II & $0.0-1.0$ & $2.0-3.0$ \\
\hline & & & $\begin{array}{l}\text { Kambodiya } \\
21.36 \text { '24" }{ }^{\circ} \mathrm{N} \\
73.21 ' 211^{\circ} \mathrm{E}\end{array}$ & October & Solar 76 BG II & $0.0-0$ & $0.0-0.0$ \\
\hline & & & $\begin{array}{c}\text { Chiklota } \\
21.37^{\prime} 53^{\prime \prime}{ }^{\circ} \mathrm{N} \\
73.18^{\prime} 36^{\circ}{ }^{\circ} \mathrm{E}\end{array}$ & October & Ajeet 155 BG II & $0.0-0.0$ & $0.0-2.0$ \\
\hline & & \multirow[t]{2}{*}{ Vagra } & $\begin{array}{c}\text { Kesavan } \\
21.866^{\prime} 65^{\circ}{ }^{\circ} \mathrm{N} \\
72.69^{\prime} 91^{\circ}{ }^{\circ} \mathrm{E}\end{array}$ & October & Kaveri BG II & $0.0-3.0$ & $0.0-1.5$ \\
\hline & & & $\begin{array}{c}\text { Khojbal } \\
21.73 \text { '92" }{ }^{\circ} \mathrm{N} \\
72.74 ' 62 \text { " }{ }^{\circ} \mathrm{E}\end{array}$ & October & Solar 77 BG II & $0.0-2.5$ & $0.0-0.0$ \\
\hline
\end{tabular}




\begin{tabular}{|c|c|c|c|c|c|c|c|}
\hline & & Amod & $\begin{array}{c}\text { Kothi } \\
21.99^{\prime} 61^{\prime \circ} \mathrm{N} \\
72.89^{\prime} 63^{\circ}{ }^{\circ} \mathrm{E}\end{array}$ & October & Solar 78 BG II & $0.0-12.0$ & $2.0-4.0$ \\
\hline \multirow[t]{2}{*}{3} & \multirow[t]{2}{*}{ Narmada } & Rajpipla & $\begin{array}{c}\text { Badam } \\
21.90^{\prime} 40^{\circ}{ }^{\circ} \mathrm{N} \\
73.499^{\prime} 50^{\circ} \mathrm{E}\end{array}$ & October & Solar 78 BG II & $2.0-3.0$ & $0.0-0.0$ \\
\hline & & Rajpipla & $\begin{array}{c}\text { Mota } \\
\text { Limatvada } \\
21.83^{\prime} 27^{\prime \prime}{ }^{\circ} \mathrm{N} \\
73.50^{\prime} 77^{\prime}{ }^{\circ} \mathrm{E}\end{array}$ & October & BG II & $2.0-4.5$ & $0.0-1.0$ \\
\hline
\end{tabular}

*Bacterial leaf blight (BLB)

*Alternaria leaf blight (ALB)

Fig.1 Word cloud from Introduction

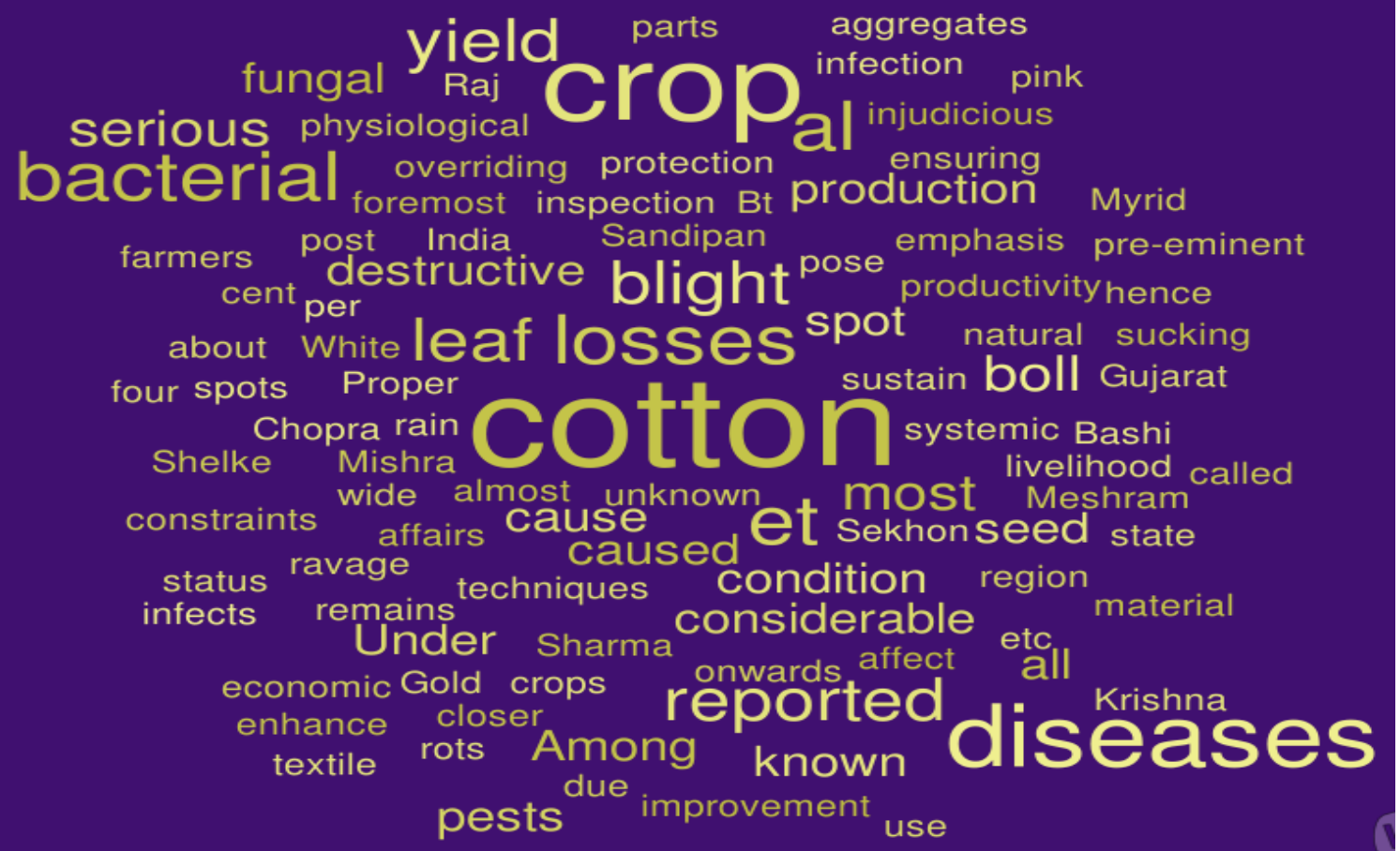


Graph.1Shows the Bacterial blight intensity, PDI (Maximum grade was taken)

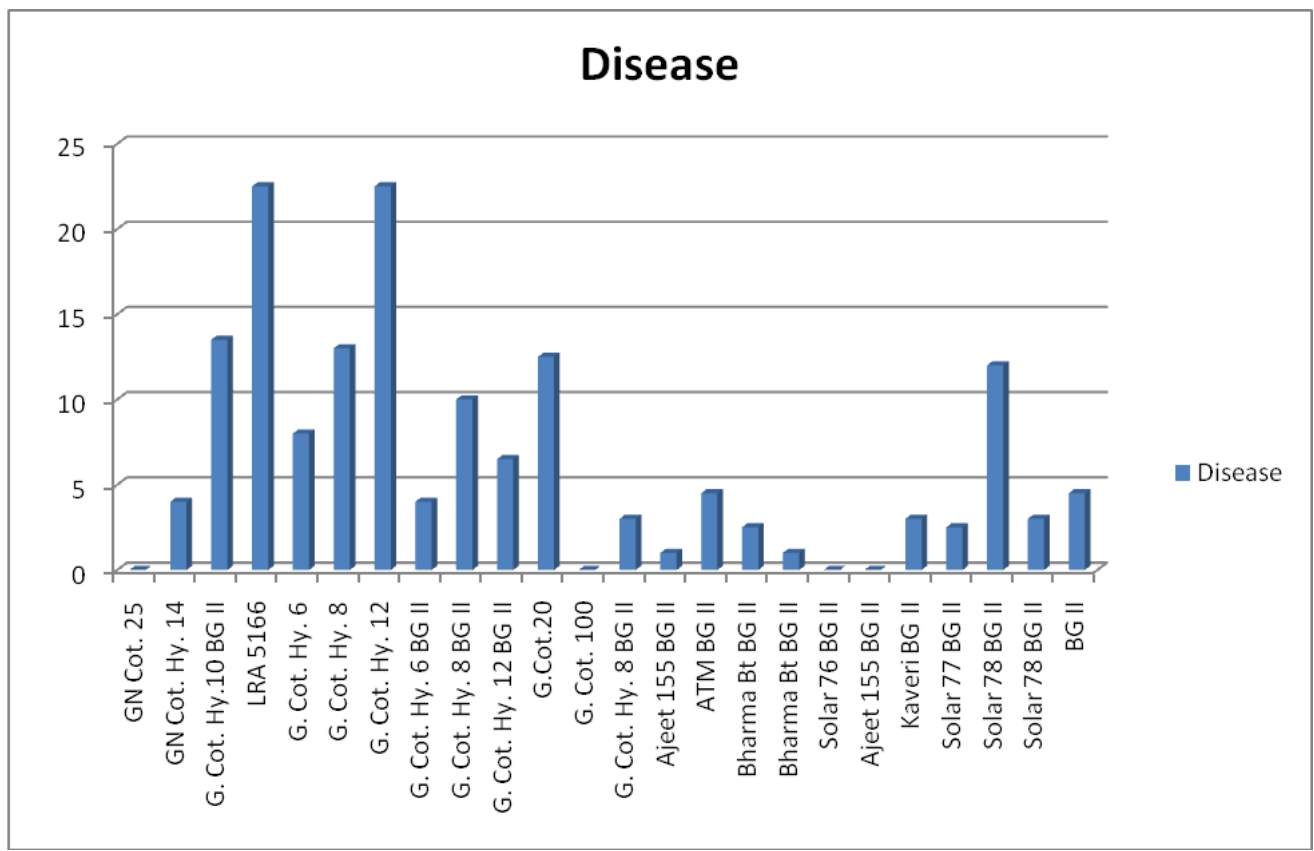

Graph.2 Shows the Alternaria leaf blight, PDI. (Maximum grade was taken)

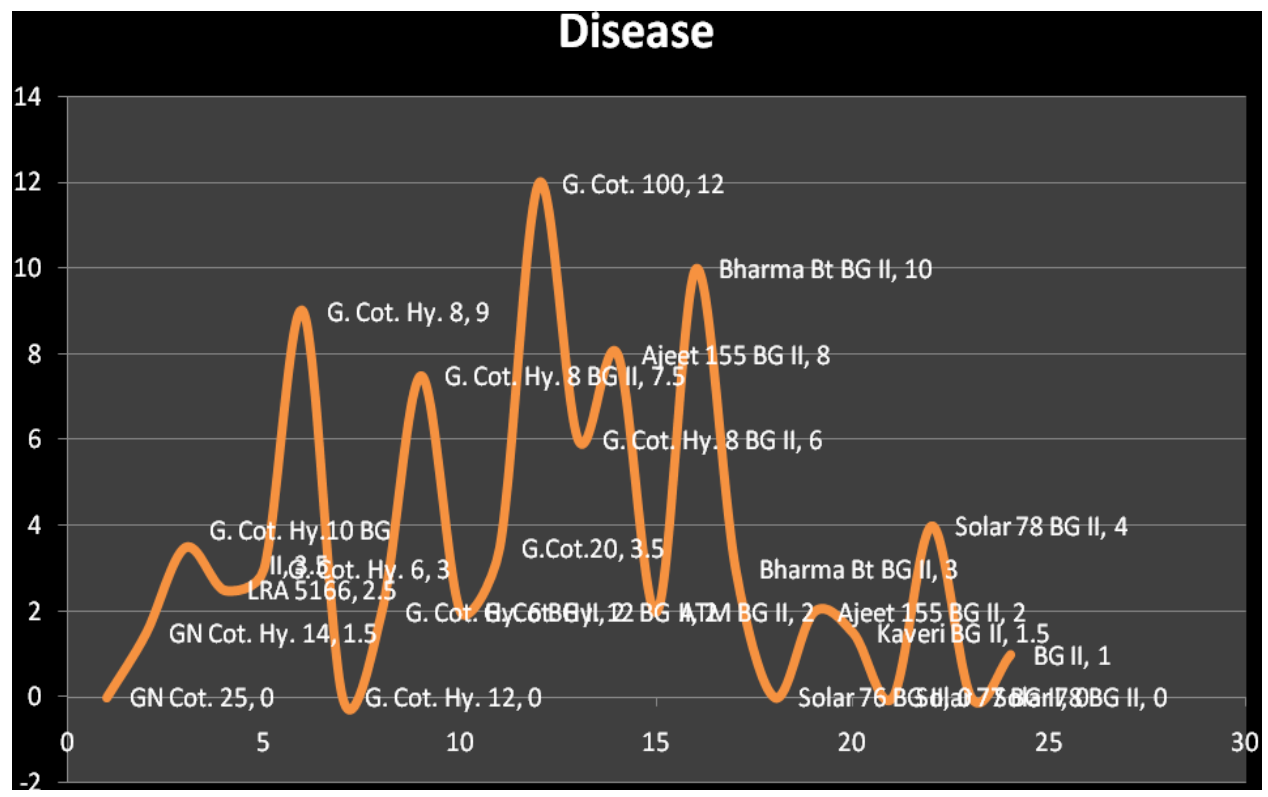

The incidence of Bacterial leaf blight disease was in the range of 0.0 to $4.5 \%, 0.0$ to $12.0 \%$ and 2.0 to 4.5 PDI in Surat, Bharuch and Narmada districts, respectively on cultivars fields in majority cultivated areas of BG II hybrids. However in Vad village of Mangrol taluka of Surat district, Para wilt symptoms were observed in the range of 0.0 to $20.0 \%$. Moreover, in case of Alternaria leaf spot disease it was observed in the tune of 0.0 to 
$8.0 \%, 0.0$ to $10.0 \%$ and 0.0 to $1.0 \mathrm{PDI}$ in Surat, Bharuch and Narmada district, respectively as shown in the Graph: $1 \& 2$.

\section{Acknowledgement}

Author is highly thankful to main Cotton Research Station (MCRS), NAU, Surat (Gujarat) for providing the required facility and other necessary arrangements for conducting the experiment in an efficient way.

\section{References}

Bashi, E., Sachs, Y. and Rotem, J. 1983. Phytoparasitica, 11: 89-97.

Chopra, B. L. 1977. Important diseases of cotton and their control measures in India. Paper presented at staff course on cotton production, its processing and marketing technology held at P.A.U., Ludhiana.

Kalpana, P., Chellamuthu, V. and Jeyalakshmi, C. 2004. Screening of cotton hybrids against bacterial blight incited by Xanthomonas campestris pv. malvacearum (Smith) Dye, Paper presented in Inter. Symp. Strat. Sust. Cotton Prod. - A Global Vision 3, Crop Production, 23-25 Novermber 2004, Univ. Agric. Sci., Dharwad (India), pp. 373-374.

Meshram, M. K. and Sheo, Raj. 1988. Assessing losses due to bacterial blight diseases. Plant Pathology. The Tata McGraw Hill Publ. Co. Ltd., New Delhi, pp. 315.

Mishra, S. P. and Krishna, A. 2001. Assessment of yield potential losses due to bacterial blight of cotton. Journal of Mycology and Plant Pathology, 31: 232-233.
Prashant B. Sandipan, Bhanderi, G.R., Patel, R.D., Desai, H.R. and Solanki, B.G. (2016). Survey and occurrence of different diseases of cotton in cultivators' and farmers field under South Gujarat condition. International. J. Plant Sci., 1 (2): 278-281.

Sharma, B. K. and Chauhan, M. S. 1985. Studies on the chemical control of foliar diseases of cotton in Haryana state. Agric. Sci. Digest. 5: 153-56.

Sekhon, P. S., Singh, D. and Singh, G. 2008. Cotton pathology research achievements and targets in Punjab. All India Coordinated Cotton Improvement Project Report. PAU, Ludhiana.

Sheoraj and Verma, J. P. 1988. Diseases of cotton in India and their management. Review of Tropical Plant Pathology, 5: 207-254.

Sheoraj. 1989. Grading system for cotton disease. CICR Publication, Nagpur.

Shelke, G. V., Aurangabadkar, L. P., Kashikar, A. R., Wadyalkar, S. R., Phalak, M. S., Khsrkar, H. H. and Umslkar, G. V. 2012. Identification of resistance source for Bacterial blight disease caused by Xanthomonas axonopodis pv. malvacearum and its genetic inheritance in upland cotton. Cotton Research Journal, 3 (2): 167-173.

Tanweer, Asif. 2013. Pesticides in Cotton - The Road Ahead. National convention on India cotton: Gearing up for Global leadership. Pp. P 9-11.

Wheeler, B. E. J. 1969. An Introduction of Plant Disease, John Wiley and Sons Limited, London, p. 301.

\section{How to cite this article:}

Prashant B. Sandipan, R. K. Patel, G. O. Faldu and Patel, D. M. 2019. Status of Different Diseases of Cotton under South Gujarat Region of India. Int.J.Curr.Microbiol.App.Sci. 8(10): 2651-2657. doi: https://doi.org/10.20546/ijcmas.2019.810.306 